\title{
EVALUATION OF CARDIOVASCULAR SYSTEM REACTIONS WHEN DIFFERENT MUSCLE GROUPS ARE ACTIVATED
}

\author{
Inga Muntianaitè ${ }^{1}$, Vytautas Poškaitis ${ }^{1}$, Alfonsas Vainoras ${ }^{1}$, Jonas Poderys ${ }^{1,2}$, \\ Sandra Bardauskiené ${ }^{1}$ \\ Lithuanian University of Health Sciences ${ }^{1}$, Kaunas, Lithuania \\ Lithuanian Academy of Physical Education ${ }^{2}$, Kaunas, Lithuania
}

\begin{abstract}
Research background and hypothesis. In our study, the dynamics of working muscle oxygen saturation of participants in the final stages of provocative bicycle ergometer test was different. According to this, we hypothesized, that different central and peripheral reaction of cardiovascular system would dominate during local and regional exercises, too.

Research aim was to evaluate central and peripheral reaction of cardiovascular system when different muscle groups are activated.

Research methods. Twenty seven healthy men (age $32 \pm 1.8$ years, body mass index $25.3 \pm 0.6 \mathrm{~kg} / \mathrm{m}^{2}$ ) participated in the study. All participants performed provocative bicycle ergometer test, electrocardiogram and oxygen saturation were registered. The participants performed three exercises activating different muscle groups: calf, forearm and back extension.

Research results. Variation of heart rate and oxygen saturation values highlighted the difference between arm and leg training exercises. However, the load for arms and legs was individualised, both Groups A and B were different according to the dynamics of heart rate and oxygen saturation indices.

Heart rate reaction to the physical load for the back muscles was unusual - heart rate decreased during the first seconds of the back load. Oxygen saturation was lower in resting back muscles compared to those of resting arm and leg muscles $(\mathrm{p}<0.05)$.

Discussion and conclusions. The analysis of heart rate and oxygen saturation values has revealed that each functional muscle group of the human organism contains not only general but also individual activating features both integrating regulatory systems and forming a certain activation of metabolism in working muscles.
\end{abstract}

Keywords: heart rate, oxygen saturation, variation of indices.

\section{INTRODUCTION}

$\mathrm{T}$ he main function of sceletal muscle is to perform mechanical work at the expence of potential chemical energy, usually for postural support and movements. However, sceletal muscle does not act alone. Important communication and coadaptation at the whole organism level must take place to optimize muscle function. For example, the rate of oxygen and extramuscular fuel supply must be closely matched to muscle demand (Storey, 2004).

Efficiency of muscles is greatly influenced by their supply of blood (Poderys et al., 1998). The intensity of blood circulation of muscles is controlled by combining the changes of heart 
function and general peripheral resistance (Lash, 1996).

Near-infrared Spectroscopy (NIRS) is becoming a widely used instrument for measuring tissue $\mathrm{O}_{2}$ status (Ferrari et al., 2004). Oxygen saturation measure shows how much oxygen the blood carries as a percentage of the maximum it could carry. M. Beekvelt et al. have shown that NIRS is able to discriminate between the resting and exercising states of the muscles (Beekvelt et al., 2001).

A lot of studies were done to examine the oxygenation levels of the vastus lateralis muscle during incremental work test. All these studies demonstrate a decrease in $\mathrm{StO}_{2}$ that occurred gradually in proportion to the increasing work rate (Belardinelli et al., 1995; Bhambhani et al., 2001). In our study, the dynamics of oxygen saturation of some participants was slightly unusual $-\mathrm{StO}_{2}$ increase in the final stages of provocative bicycle ergometer test. According to the dynamics of oxygen saturation in the final stages of bicycle ergometer test, the participants were divided into two groups: Group A - with the increase of $\mathrm{StO}_{2}$ in the final stages of the workload and Group B - with the decrease of $\mathrm{StO}_{2}$ in all stages of the workload. We hypothesized, that different $\mathrm{StO}_{2}$ dynamics and heart rate in $\mathrm{A}$ and $\mathrm{B}$ group would dominate during local and regional exercises as well.

The aim of the work was to evaluate central (heart rate) and peripheral (oxygen saturation) reaction of cardiovascular system when different muscle groups were activated.

\section{RESEARCH METHODS}

Twenty seven men (age $32 \pm 1.8$ years, body mass index $25.3 \pm 0.6 \mathrm{~kg} / \mathrm{m}^{2}$ ) participated in the study. All of them were apparently healthy without any history of chronic disease. Subjects did not smoke, nor did they take any medications. None of them had previously participated in regular exercise training.

The evaluation of the heart rate was based on the electrocardiogram analysis system „Kaunasload", created at the Institute of Cardiology of the Lithuanian University of Health Sciences. Synchronous 12 lead Electrocardiogram was registered and analyzed during the exercise and the first four minutes of recovery.

The variation of oxygen saturation $\left(\mathrm{StO}_{2}\right)$ in the muscles during the workload and after it was estimated by the non-invasive Near-infrared Spectroscopy Method (NIRS) with the application of a photo sensor (Hutchinson Technology, Hutchinson, Minnesota USA). A photo sensor was placed on the main group of muscles performing a movement.

All participants performed provocative bicycle ergometer test, ECG and oxygen saturation were registered. According to the dynamics of oxygen saturation in the final stages of bicycle ergometer test, the participants were divided into two groups: Group A - with the increase of $\mathrm{StO}_{2}$ in the final stages of the workload $(n=15)$ and Group B - with the decrease of $\mathrm{StO}_{2}$ in all stages of the workload $(n=12)$.

The present work deals with the analysis of the heart rate (HR) and $\mathrm{StO}_{2}$ indices of the participants who performed three exercises activating different muscle groups. The exercises consisted of calf, forearm and back extension.

The protocols of calf and forearm extension exercises (Figure 1) were analogous: the participants underwent a capacity estimation test for the functional group of the muscles participating in the exercise. An individual weight, which constituted 50 percent of the maximum, was chosen for the test. Then the participants performed three local workloads. The movement
Figure 1. Protocol of calf and forearm extension exercises

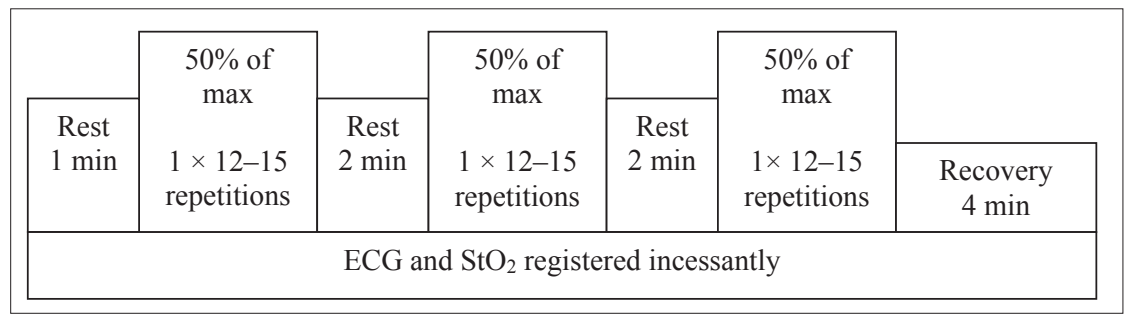

Figure 2. Protocol of back extension exercise

\begin{tabular}{|c|c|c|c|c|c|c|}
\hline \multirow{2}{*}{$\begin{array}{l}\text { Rest } \\
1 \mathrm{~min}\end{array}$} & & \multirow{2}{*}{$\begin{array}{l}\text { Rest } \\
2 \mathrm{~min}\end{array}$} & & \multirow{2}{*}{$\begin{array}{l}\text { Rest } \\
2 \mathrm{~min}\end{array}$} & & \multirow{2}{*}{$\begin{array}{c}\text { Recovery } \\
4 \mathrm{~min}\end{array}$} \\
\hline & $\begin{array}{l}1 \times 3 \\
\text { repetitions }\end{array}$ & & $\begin{array}{l}\quad 1 \times 3 \\
\text { repetitions }\end{array}$ & & $\begin{array}{l}1 \times 3 \\
\text { repetitions }\end{array}$ & \\
\hline \multicolumn{7}{|c|}{ ECG and $\mathrm{StO}_{2}$ registered incessantly } \\
\hline
\end{tabular}


performing extension took 2 seconds and returning to the initial position $-2-3$ seconds, the number of repetitions was $12-15$, the number of sets was 3. Resting intervals between sets were 2 minutes. ECG and oxygen saturation were incessantly registered 1 minute before the workload, during it, after each workload in resting position and four minutes after the exercise. Each workload was divided into 2 stages, rest - in 4, recovery - in 4 . We calculated means and SD.

For the back muscle training, the participants performed three trunk extension exercises leaning on thighs on an exercise machine. Making a move, the participants performed trunk extension -10 seconds and returned to the initial position -20 25 seconds. Rest intervals between workloads were 2 minutes in a standing position. ECG was registered 1 minute before the exercise, during the workload and at rest. The variation of oxygen saturation was incessantly registered in the back muscle ( $m$. erector spinae). After the final load ECG and $\mathrm{StO}_{2}$ were further registered for the first four minutes in the standing position (Figure 2). Each workload was divided into 3 stages, rest - in 4 , recovery - in 4 . We calculated means and SD.
The data of the study were processed with the help of SPSS statistical package. The following statistical criteria were applied: Wilcoxon criterion, was applied for dependent samples, when analysing a statistically significant difference between the indices registered at different periods of exercises and performed by the same group of participants; Mann-Whitney criterion was applied for independent samples, when analysing a statistically significant difference between the indices of different groups of the participants. The difference was considered statistically significant when $\mathrm{p}$ was $<0.05$ (95\% of confidence intervals).

\section{RESEARCH RESULTS}

The analysis of variation of HR while performing repeated exercises for leg and arm muscle training revealed differences between Group A ( $\mathrm{StO}_{2}$ increased $)$ and Group $\mathrm{B}\left(\mathrm{StO}_{2}\right.$ decreased) (Table). Statistically significant HR was in rest and recovery stages of exercise for leg muscles, and in all stages performing physical task by arms (Table) it was higher in Group A than that

\begin{tabular}{|c|c|c|c|c|}
\hline \multirow{2}{*}{ Exercise stages } & \multicolumn{2}{|c|}{ Leg exercise } & \multicolumn{2}{|c|}{ Arm exercise } \\
\hline & Group A & Group B & Group A & Group B \\
\hline Rest & $84 \pm 8 \bullet \square$ & $76 \pm 6 \bullet$ & $97 \pm 8 \circ \square$ & $91 \pm 11 \circ$ \\
\hline Load stage 1 & $95 \pm 8 \square$ & $97 \pm 9$ & $108 \pm 10 \circ \square$ & $99 \pm 10 \circ$ \\
\hline Load stage 2 & $109 \pm 10 \square$ & $110 \pm 5$ & $118 \pm 11 \circ \square$ & $108 \pm 11 \circ$ \\
\hline Rest stage 1 & $95 \pm 7 \bullet \square$ & $86 \pm 6 \bullet \mathbf{\square}$ & $107 \pm 11$ ㅁ & $98 \pm 8 \circ \mathbf{m}$ \\
\hline Rest stage 2 & $90 \pm 10 \bullet \square$ & $81 \pm 7 \bullet \square$ & $104 \pm 12$ ○ & $94 \pm 11$ ○ \\
\hline Rest stage 3 & $87 \pm 8 \bullet \square$ & $78 \pm 9 \bullet \square$ & $101 \pm 10 \circ \square$ & $92 \pm 9 \circ$ \\
\hline Rest stage 4 & $85 \pm 12 \bullet \square$ & $79 \pm 9 \bullet \square$ & $102 \pm 12$ ○ & $91 \pm 10 \circ$ \\
\hline Load stage 1 & $105 \pm 9 \square$ & $102 \pm 10$ & $111 \pm 8 \circ \square$ & $104 \pm 9 \circ$ \\
\hline Load stage 2 & $113 \pm 9 \square$ & $114 \pm 10$ & $125 \pm 15$ ○ & $114 \pm 12 \circ$ \\
\hline Rest stage 1 & $96 \pm 11 \square$ & $91 \pm 9 \square$ & $111 \pm 10 \circ \square$ & $100 \pm 9 \circ$ \\
\hline Rest stage 2 & $93 \pm 10 \bullet \square$ & $82 \pm 6 \bullet \square$ & $105 \pm 6 \circ \square$ & $96 \pm 8 \circ$ \\
\hline Rest stage 3 & $90 \pm 10 \bullet \square$ & $79 \pm 9 \bullet \square$ & $104 \pm 8 \circ \square$ & $92 \pm 9 \circ \mathbf{\square}$ \\
\hline Rest stage 4 & $89 \pm 9 \bullet \square$ & $80 \pm 10 \bullet \square$ & $103 \pm 10 \circ \square$ & $94 \pm 9 \square$ \\
\hline Load stage 1 & $105 \pm 12 \square$ & $106 \pm 11$ & $113 \pm 11 \circ \square$ & $108 \pm 10 \circ$ \\
\hline Load stage 2 & $116 \pm 11 \square$ & $117 \pm 11$ & $127 \pm 13$ ○ & $119 \pm 11 \circ$ \\
\hline 1-min recovery & $96 \pm 13 \bullet \square$ & $88 \pm 10 \bullet \mathbf{\square}$ & $110 \pm 12 \circ \square$ & $100 \pm 12$ \\
\hline 2-min recovery & $88 \pm 11 \bullet \square$ & $79 \pm 10 \bullet \mathbf{a}$ & $105 \pm 12 \circ \square$ & $95 \pm 14 \circ$ \\
\hline 3-min recovery & $91 \pm 9 \bullet \square$ & $77 \pm 10 \bullet \mathbf{\square}$ & $105 \pm 11 \circ \square$ & $93 \pm 12 \circ$ \\
\hline 4-min recovery & $89 \pm 9 \bullet \square$ & $78 \pm 9 \bullet \mathbf{\square}$ & $104 \pm 9 \circ \square$ & $95 \pm 11$ ○ \\
\hline
\end{tabular}

Table. Variation of HR (beats per minute) performing repeated exercises for arm and leg muscle training

Note. - $-\mathrm{p}<0.05$ comparing HR values of Group A to those of Group B during leg exercise; $\circ-\mathrm{p}<0.05$ comparing HR values of Group A to those of Group B during arm exercise; $\square-\mathrm{p}<0.05$ comparing HR values of leg exercise with arm exercise in Group A; - $-\mathrm{p}<0.05$ comparing HR values of leg exercise with arm exercise in Group B. 
Figure 3. Variation of HR while performing repeated exercises for back muscle training

Note. $*-p<0.05$ comparing HR values of Group A to those of Group B in the same stage of workload.

Figure 4. Dynamics of $\mathrm{StO}_{2}$ indices while performing repeated exercises for arm and leg muscle training
Note. $*-p<0.05$ comparing $\mathrm{StO}_{2}$ values of Group A to those of Group B in the same stage of workload. $\bullet-p<0.05$ comparing $\mathrm{StO}_{2}$ values of leg exercise to those of arm exercise in Group A. $\circ-\mathrm{p}<0.05$ comparing $\mathrm{StO}_{2}$ values of leg exercise to those of arm exercise in Group B.

in Group B. During arm exercise HR was higher than during leg exercises in Group A in all exercise stages $(p<0.05)$, while in Group B significant differences of HR values between arm and leg exercise were only in rest and recovery stages.

The variation of HR shows the effect of load summation in both groups performing exercise for leg and arm muscles (Table). The average of HR was statistically lower at the beginning of the first exercise load (performing leg exercise: in Group A the sum of two load stages was $102 \pm 9$ beats / min, in Group B $-103 \pm 7$ beats / min; the corresponding values performing arm exercise: in Group $\mathrm{A}-113 \pm$ 11 beats / min, in Group B $-104 \pm 11$ beats / min) than during the third one (performing leg exercise: in Group A the sum of two load stages was $110 \pm$ 12 beats / min, in Group B $-112 \pm 11$ beats / min; the corresponding values performing arm exercise: in Group A $-120 \pm 13$ beats / min, in Group B $114 \pm 12$ beats / $\mathrm{min})$.

Figure 3 shows that HR decreased during the load for back muscles. It is different than in leg and arm exercises. Repeated exercises for back muscle training also resulted in the effect of load summation. However, in reverse to arm and leg exercises, HR decreased in both groups during the back muscle exercises, but statistically significant difference was found in Group A comparing the 


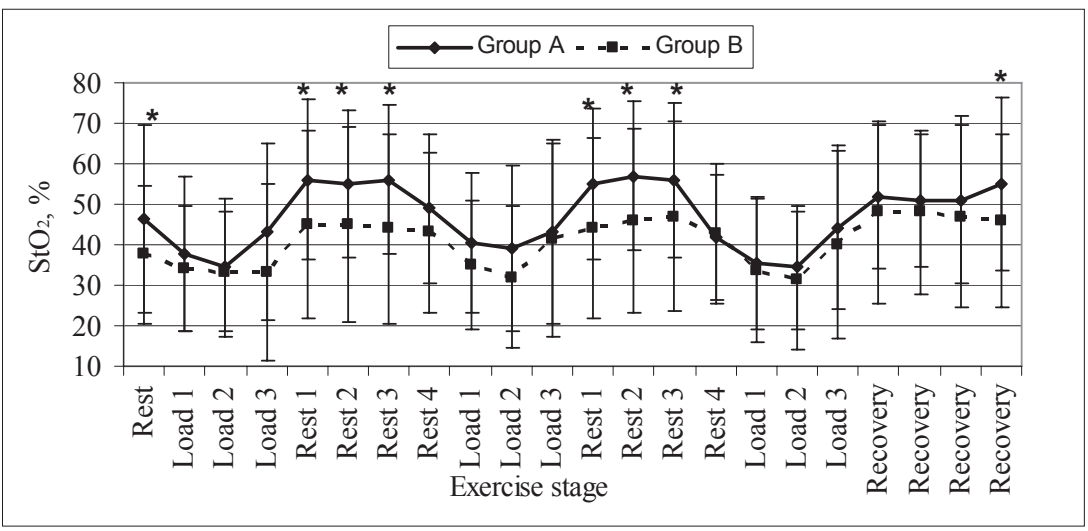

Figure 5. The dynamics of $\mathrm{StO}_{2}$ indices while performing repeated exercises for back

first and the third exercise loads (the sum of three stages of the first exercise load was $101 \pm$ 12 beats / min and during the third load $-95 \pm$ 13 beats / $\mathrm{min}$ ).

Statistically significantly lower oxygen saturation was observed in Group B during almost the whole exercise of arm training (Figure 4). The same difference occurred during the exercises of leg training with higher values in Group A, but statistically significant $\mathrm{StO}_{2}$ values were found only in some rest Stages and all recovery stages.

Statistically higher $\mathrm{StO}_{2}$ values were found during physical task for legs compared to those in arms in the last measurement at rest (during leg exercise the values of Group A were 33, 57, 54\% and Group B - 35, 52, 46\%; corresponding arm exercise values of Group A were 21, 26, 21\% and Group B $-8,12,13 \%$ ) and in the first stages of the load (during leg exercise the values of Group A were 39, 37, 33\% and Group B - 37, 29, 32\%; corresponding arm exercise values of Group A were 28, 17, 17\% and Group B - 6, 15, 20\%).

General variations in oxygen saturation during the exercise for back muscle training (Figure 5) produced about the same changes as it was found in other studies (Ozyener, 2002; Carlson, Pernow, 2008) - oxygen saturation decreased during the workload and increased during the recovery period. The tendency of smaller amount of oxygen saturation during the back exercise was determined in Group B (statistically significant difference was found not during the whole workload).

\section{DISCUSSION}

Different $\mathrm{StO}_{2}$ dynamics of participants in the final stages of the provocative bicycle ergometry test showed different relation of activated muscles and central function of the heart. The decrease of oxygen saturation during the workload shows a specific synergetic relation of skeleton muscles to the central function of the heart myocardium which maintains hemodynamics (Adams et al., 1993). Meanwhile, an increasing amount of oxygen in muscle tissue is related to the vasodilatation of peripheral vessels and is considered as a compensatory mechanism of increasing functional ischemic phenomena in myocardium (Poderys et al., 2000; Po kaitis, 2008).

Differences between Groups A and B dominated during local and regional exercises too. Analysing the dynamics of HR values, a tendency of higher values in Group A compared to Group B was noticed.

Comparing the dynamics of HR values during local exercises when different muscle groups were activated, we noticed that HR of Group A was significantly higher during arm exercises than during leg exercises in all stages. However, HR values of Group B were statistically significantly different in rest and recovery stages, but similar in load stages performing both exercises. This reveals that the subjects of Group B had a better (or different) coordination between peripheral and central circulation.

During the first seconds of the back load, HR decreased. Such dynamics of HR is difficult to compare with typical reaction to physical load for other muscle group. This could be explained by the fact that the exercise for back muscles mostly involves trunk extensors ( $m$. erector spinae antigravity muscles) which are adapted to perform static physical load (Jorgensen, Nicolaisen, 1986).

However, the load for arms and legs was individualised, both Groups A and B were different according to the dynamics of $\mathrm{HR}$ and $\mathrm{StO}_{2}$ indices. This indicates that the performance of the exercises of global and local character results in the different functioning of the regulation mechanisms of central and peripheral blood flow.

In the first stage of loads, oxygen saturation was lower for arm exercise, than in the same stage of 
the leg load in both groups $(\mathrm{p}<0.05)$. In the second stage of load $\mathrm{O}_{2}$ saturation increased and this could be related to higher activation of respiratory system. J. A. 1. Calbet et al. (2004) demonstrated lower $\mathrm{O}_{2}$ extraction in the arms than in the legs during skiing on a treadmill with different techniques: diagonal stride (combined arm and leg exercise), double poling (predominantly arm exercise), and leg skiing (predominantly leg exercise). They attributed the observed differences in maximal arm and leg $\mathrm{O}_{2}$ extraction to higher heterogeneity in blood flow distribution, shorter mean transit time, smaller diffusing area, and lager diffusing distance in arms then in legs (Calbet, 2004).

It is interesting to note that oxygen saturation began to decrease already before the load. Such reaction could be explained as precocious metabolic reaction and reflects the stage before the start (Skernevičius, 1997).

Oxygen saturation was lower in resting back muscles compared to resting arm and leg muscles $(\mathrm{p}<0.05)$. But $\mathrm{StO}_{2}$ values statistically more decreased in the arms, then in the back muscle in the first load stages (during arm exercise in Group A, the values were $28,17,17 \%$, and during back exercise - 38, 40, 36\%; in Group B during arm exercise $-6,15,20 \%$, and during back exercise $-34,35,34 \%)$. Our results are supported by R. V. Maikala and Y. N. Bhambhani (2007) who studied tissue heterogeneity in peripheral circulatory responses from two muscle groups (brachial biceps and lumbar muscles) and reported that oxygen supply and demands were regulated by muscle location and muscle fibre characteristics.

\section{CONCLUSIONS AND PERSPECTIVES}

The analysis of HR and oxygen saturation indices has revealed that each functional muscle group of the human organism contains not only general but also individual activating features both integrating regulatory systems and forming a certain activation of metabolism in working/functioning muscles. The evaluation of the variation of HR during local and regional workloads indicated the different impact of regulatory systems to activated muscles. Oxygen saturation was lower in the resting back muscles compared to arm and leg muscles but it was higher during the first stages of workloads.

The calculation of the dynamics and absolute values of the variation of indices revealed differences between the chosen groups during different physical tasks.

\section{REFERENCES}

Adams, G. R., Hather, B.,M., Baldwin, K. M. (1993). Skeletal muscle miosin heavy chain composition and resistance training. Journal of Applied Physiology, 74, 911-915.

Beekvelt, M., Colier, W., Wevers, R. A., Van Engelen, B. G. (2001). Performance of near-infrared spectroscopy in measuring local $\mathrm{O}_{2}$ consumption and blood flow in sceletal muscles. Journal of Applied Physiology, 90, 511-519.

Belardinelli, R., Barstow, T. J., Porszasz, J., Wasserman, K. (1995). Changes in sceletal muscle oxygenation during incremental exercise measured with near infra-red spectroscopy. Medicine \& Science in Sports \& exercise, 70, 487-492.

Bhambhani, Y., Maikala, R., Esmail, S. (2001). Oxygenation trends in vastus lateralis muscle during incremental arm and leg exercise in man and women. European Journal of Applied Physiology, 84, 547-546.

Calbet, J. A. L., Holmberg, H. C., Rosdahl, H. et al. (2004). Why do arms extract less oxygen than legs during exercise. American Juornal of Physiology-Regulatory, Integrative and Comparative Physiology, 289, 1448-1458.

Carlson, L. A., Pernow, B. (2008). Sudies on the peripheral circulation and metabolism in man Oxygen utilization and lactate-pyruvate formation in the legs at rest and during exercise in healthy subjects. Acta Physiologica Scandinavica, 3-4 (52), 328-342.

Ferrari, M., Mottola, I., Quaresima, V. (2004). Principles, techniques and limitations of near infrared spectroscopy. Canadian Journal of Applied Physiology, 29 (4), 463-87.
Jorgensen, K., Nicolaisen, T. (1986). Two methods for determining trunk extensor endurance. European Journal of Applied Physiology, 55, 639-644.

Lash, J. M. (1996). Regulation of sceletal muscle blood flow during contractions. Proceedings of the Society for Experimental Biology and Medicine, 211 (3), 218-35.

Maikala, R. V., Bhambhani, Y. N. (2007). Peripheral circulatory responses in vivo from regional brachial biceps and lumbar muscles in healthy men and women during pushing and pulling exercise. Gendre Medicine, 2 (4), 130-145.

Ozyener, F. (2002). Evaluation of intra-muscular oxygenation during exercise in humans. Journal of Sport Science and Medicine, 1, 15-19.

Poderys, J. (2000). Fast and Slow Adaptation Feature of the Cardiovascular System, Performing Exercise: Habilitation Thesis. Kaunas.

Poderys, J., Trinkūnas, E., Šilinskas, V. (1998). Arterinio perfuzinio slègio itaka blauzdos raumenų darbingumui ir kraujotakai. Sporto mokslas, 3 (12), 15-19.

Poškaitis, V. (2008). Synergy of Muscles and Cardiovascular System Performing Physical Loads: Doctoral dissertation. Kaunas.

Skernevičius, J. (1997). Physiology of the workout. Vilnius.

Storey, K. B. (2004). Functional Metabolism: Regulation and Adaptation. John Wiley \& Sons. 


\title{
ŠIRDIES IR KRAUJAGYSLIŲ SISTEMOS REAKCIJOS ANALIZE் AKTYVUOJANT SKIRTINGAS RAUMENŲ GRUPES
}

\author{
Inga Muntianaitė ${ }^{1}$, Vytautas Poškaitis ${ }^{1}$, Alfonsas Vainoras ${ }^{1}$, Jonas Poderys ${ }^{1,2}$, \\ Sandra Bardauskien $\dot{e}^{1}$ \\ Lietuvos sveikatos mokslu universitetas ${ }^{1}$, Kaunas, Lietuva \\ Lietuvos kūno kultūros akademija², Kaunas, Lietuva
}

\section{SANTRAUKA}

Tyrimo pagrindimas ir hipotezè. Atliekant provokacini pakopomis didinamą fizini krūvị, dirbančio raumens deguonies įsisotinimo kaita paskutiniais krūvio etapais buvo skirtinga. Darome prielaida, kad šis skirtumas gali lemti nevienodas centrinès bei periferinès kraujotakos reakcijas dirbant rankų, kojų ir nugaros raumenims.

Tikslas: ivvertinti centrinès ir periferinès širdies ir kraujagyslių sistemos reakcijas aktyvuojant skirtingas raumenų grupes.

Metodai. Ištirti 27 sąlygiškai sveiki vyrai (amžius $32 \pm 1,8 \mathrm{~m}$., KMI 25,3 $\pm 0,6 \mathrm{~kg} / \mathrm{m}^{2}$ ). Visi tiriamieji atliko pakopomis kas minutę didinamą provokacini fizini krūvị veloergometru. Jo metu buvo registruojama elektrokardiograma ir vertinamas deguonies issisotinimas neinvaziniu artimosios infraraudonosios spektroskopijos būdu. Tiriamieji suskirstyti i dvi grupes pagal deguonies ịsisotinimą paskutiniais veloergometrinio krūvio etapais: A grupè - deguonies issisotinimas didèjo paskutiniais veloergometrinio krūvio etapais; B grupè - deguonies isisotinimas mažèjo visais krūvio etapais. Jie tiesè blauzdą, dilbị ir nugarą.

Rezultatai. Širdies susitraukimų dažnio ir deguonies issisotinimo rodiklių kaita parode skirtumus tarp rankomis ir kojomis atliekamo pratimo. Nors krūvis rankoms ir kojoms buvo individualizuotas, A ir B grupés širdies susitraukimu dažnio ir deguonies įsisotinimo rodiklių kaita skyrėsi.

Kiek neịprasta širdies susitraukimų dažnio reakcija taikant fizinị krūvị nugaros raumenims - širdies susitraukimų dažnis pirmomis krūvio sekundèmis sumažėdavo, bet ne padidèdavo. Ramybės sąlygomis užregistruotas deguonies įsisotinimas nugaros raumenyse buvo mažesnis nei rankų ir kojų $(\mathrm{p}<0.05)$.

Aptarimas ir išvados. Širdies susitraukimų dažnio ir deguonies įsisotinimo rodiklių kitimas aktyvuojant skirtingas raumenu grupes parodè, kad kiekviena funkcinè raumenu grupé žmogaus organizme turi ne tik bendrujų, bet ir savujų aktyvavimo ypatybių, tiek įsitraukiant reguliacinèms sistemoms, tiek formuojant tam tikrą metabolizmo aktyvavimą dirbančiuose raumenyse.

Raktažodžiai: širdies susitraukimų dažnis, deguonies įsisotinimas, rodiklių kitimas.

Gauta $2011 \mathrm{~m}$. kovo $10 \mathrm{~d}$.

Received on March 10, 2011

Priimta $2011 \mathrm{~m}$. birželio $16 \mathrm{~d}$.

Accepted on June 16, 2011
Corresponding author Inga Muntianaite Lithuanian University of Health Sciences A. Mickevičius str. 9, LT-44307 Kaunas Lithuania

Tel +370 37730580

E-mail ingamd@mail.lt 